\title{
HIJAZI HOUSE: GENDERED SPACE AND CULTURAL RELATIONS
}

\author{
ALAA ZAHER Q. AL-BAN \\ Interior Design Department, Dar Al-Hekma University, Saudi Arabia
}

\begin{abstract}
Because of Makkah and Madinah, the two holiest sites in Islam, Hijaz in western Saudi Arabia is the most important religious province. The traditional Hijazi residence in Jeddah has evolved significantly over time but provides a case study for how the social and cultural values, particularly the separation of men and women, are manifested in its spatial organization. Traditionally, public spaces are the male domain and the private spaces are those of the female and family. The purpose was to provide total privacy and seclusion for women and reflects the broader social practice requiring women to cover up in public or in front of non-family males. This social organization is reflected in the spatial layout of the remaining Hijazi residences in Jeddah. Pejorative phrases such as "the segregation of women" or "the seclusion of women" are common in the west when gender relations in Islam are discussed. In contrast, this paper will cast light on how the spatial organization of the traditional Hijazi residence serves women's needs, comfort, and privacy and how it evolved to maintain cultural relations in the $19^{\text {th }}$ century. Photographs and drawings will demonstrate the power of social values in the architecture of the Hijazi House.
\end{abstract}

Keywords: Hijazi architecture, Islamic gender relations, roshan, female agency, Saudi architecture.

\section{INTRODUCTION}

Saudi Arabia's primary language is Arabic and the dominant religion is Islam. One of the five pillars and duties of Islamic faith is the Hajj Pilgrimage, which requires all able-bodied Muslims around the world to make the journey to Makkah, which houses the Kabaa. And the holy mosque in Madinah which house the prophet Mohammed Peace Be Upon Him grave, at least once in their lifetime. This birthplace of Islam and home to the two holiest shrines is located in the western region of Saudi Arabia Hijaz. Religious tourism has made it the most diverse and multicultural region in Saudi Arabia, bringing in people from many different parts of the world. Jeddah, one of the major cities of Hijaz, is the only gate for these holy cities. Because the Hajj is one of the largest annual human gatherings in the world, it has impacted the architecture and trade of Jeddah specifically and the Hijaz region generally. Due to Jeddah's location, it functions as the port to the two holy cites and wields an ideological significant and political influence over the world's 1.6 billion Muslims, $23 \%$ of the world's population.

Thus, this research is situated at the intersection of identity, space, and gender. It seeks to raise awareness that will help shape the future of architectural design in Saudi Arabia, one that retains culture and ultimately helps others understand the power culture has on the built form in general and in Jeddah specifically. Even more so, foster recognition of existing architectural strategies that reflects one's culture and, therefore, one's needs. By bringing together diverse methodological and theoretical concerns, this research reveals how interdisciplinary scholarship raises awareness and shapes the future of architectural design, a future that seeks to retain culture. Many researchers have Bayt Nassief as a case study, but few have done so with a close examination of its gendered spaces which will be the focus of this research. 


\section{CULTURAL FORMATION}

Defining the term culture is not an easy task. Culture is a medium that varies from place to place due to the differences in beliefs, locations, climates, and trends. The search for and ability to define one's identity is a distinctive human drive; it importantly explains the duality of sameness and uniqueness; it gives meaning to human existence [1]. To better understand their relationship to location, people throughout history have used various media to express their identity such as clothing, art, food, language. Architecture is yet another key medium of expression. It displays the unique traditions of individuals and societies according to the norms of a culture.

Due to Jeddah's proximity to Makkah and Madinah, the city is still the commercial center of the western Arabian Peninsula. An influx of visitors from around the world has resulted in the settlement of permanent visitors, or those who have chosen to make Jeddah their home. Over time, these external influences have been adopted, and coupled with strong local customs, all of which have given its inhabitants a distinctive identity. The locals adopted some customs, merged them with their own norms and habits, and incorporated them into Hijazi culture and tradition.

\subsection{Religion/Islam}

The values and culture embedded in Jeddah's architecture was significantly affected by the coming of Islam [2]. Alongside the unique ideological structure of Islam, the aesthetic tastes of the Prophet PBUH were simple and modest, and, in line with building traditions, his house in Madinah consisted of a large courtyard with long galleries and a row of simple rooms. The design prioritized privacy, one of the most important Islamic traditions. The haramlik, or the women's majlis (a salon, or living room), is the private space of women, children, and the head of the family. Male guests are excluded and are received in the majlis near the entrance.

The culture and values ushered in with the Islamic period - specifically after the founding of Saudi Arabia - affected the different forms of architecture within Saudi Arabia's regions. Echoing Ragette, King notes in his book, The Traditional Architecture of Saudi Arabia, that the general character of the Saudi environment and its dense settlement configurations led to an attitude of seclusion [3]. Islamic notions about the nature of the family strengthened the trend to introversion. Both King and Ragette understands how the rules laid down in the Qur'an determine a certain way of architectural planning and design. All Muslims take their Shariaa, or Islamic law, from the Qur'an. In regard to architectural design, the Qur'an dictates that the wife is muhasana, or a woman that must be guarded by her husband so that her honor is not violated. All Islamic domestic architecture, therefore, is built around the privacy of women. The Qur' an consists of 141 Sura, or chapters, and Sura AlNoor, the Light, prescribes:

1. O you who have believed, do not enter houses other than your own houses until you ascertain welcome and greet their inhabitants. That is best for you; perhaps you will be reminded [4].

Thus, closing the house to the outside is a necessity. While the entry side of the courtyard is still a semi-public space, it typically progresses into a semi-private area on the women's side. Usually, notice is given of any approaching visitor, and the family will act accordingly. Women will put on veils or retreat to their quarters.

Two Arab Muslim architectural scholars also make note of the smooth and clear connection between Shariaa, and the architectural form of the home. Salem Sharif provides a macro perspective of how culture and tradition effect the form of the Islamic courtyard 
house [5], while Sameer Al-Lyaly, in his $\mathrm{PhD}$ dissertation, gives a micro perspective of how culture and tradition affect the form of the traditional house in Jeddah [6]. They both understand that the traditions and customs of Arab and Islamic families require women to cover up while in public or in front of male strangers. But other scholars, especially Western scholars, do not understand these traditions, and instead use the phrases "segregation of women" and "seclusion of women" when talking about the culture of Arabs and/or Muslims and, therefore, Saudis [7].

\section{WOMEN AGENCY AND THE HIJAZI HOUSE}

In Saudi Arabia, as in many Middle Eastern cultures and societies, family relations and social structure are tied to the Islamic religion. Power is embedded in these different roles, and social hierarchies emerge within these religious constraints. While men do have dominant political voice in Islam, women are allotted spaces of empowerment as well, despite what many assume about Islam's constraints. The $19^{\text {th }}$ century design of the houses in Jeddah reveals that women historically in fact employed significant authority over their self, their representation, and the rules that governed their domestic domain.

Before examining the way a Muslim woman's agency is inscribed in her home, the very concept of agency must be addressed. Taking the definition of agency that which Saba Mahmood, in her book, The Politics of Piety, offers [8]. This is a concept of agency that reveals itself in the "Women's Mosque Movement" in Cairo, Egypt, studied by Mahmood. Agency for Mahmood is not a Western Enlightenment transcendental, trans-historical, and universal category. It is like, most human concepts, an experience that is relative to one's socio political and economic context. Thus, we must understand that the $19^{\text {th }}$ century Muslim Hijazi woman enjoyed real authority in her world an agency that Westerners typically discount.

Women were the principal occupants and users of the Hijazi house. As the teacher of her children, mistress of the servants, the "king" of her castle - particularly because the man was out for most of the day, the woman of the home was the principal authority figure. Thus, the home offered her a very significant playing field on which to enact her agency. A key way that these houses acquire meaning lies in the way they signify a woman's status in Hijazi culture. This analysis looks particularly at how power and status are expressed through public reception and in the private sphere.

\subsection{Public reception}

1. Location of the house: for optimum viewing and social implications.

2. Exterior facade: visually expressive, luxurious materials and details that are apparent to the public. Women have equal authority and responsibilities with men in the public presentation of the family. The height and elevation is measure of status.

\subsection{Private sphere}

1. Location of entrances and how the building is made accessible for women and others, and how women use there entrance.

2. Floor plans and elevations: reveal the control of spaces and the symbolism located inside. 
3. Certain percentages of the floor plan are used, controlled, and occupied by women exclusively.

4. Vertical elevation positioning, especially the terrace, provide a breeze-filled area above the dirt and smells of the street.

5. Materials used are luxurious, often chosen by the women, with the men mostly providing support, depending on their status and social presentation.

\section{PUBLIC PRESENTATION AND THE STATUS IN AL-BALAD HOUSES}

Scholars who work on these houses tend to focus on the structure itself at the expense of understanding it within its urban content as a signifier of status. Discussions of the traditional houses in Hijaz, such as King's Traditional Architecture of Saudi Arabia; consider houses like Bayt Ridwan, Bayt Al-Shurbatli, Bayt Nassif, and Bayt Al-Baghdadi, only in terms of decorative elements for these structures, and really, he primarily examines Bayt Nassief.

Yet it is important to understand that these Jeddah homes were active urban units comprising one part of the city. They were a typo-morphological response to climate, material, and socio-spatial practices. In fact, at the height of their popularity, the tall roshan tower house of Jeddah was the primary and basic urban unit of Jeddah. Thus, it played a critical role in shaping the city's urban fabric composed of tightly knit neighborhoods with integrated residential and commercial functions and an organized main marketplace. Though Jeddah's style of architecture was similar to that found in other Red Sea coastal cities such as Yunbu and Sawakin, and, to some extent, to Makkah, Al-Taif and Madinah, the visual and spatial characteristics of these structures uniquely contributed to the shaping of Jeddah's urban morphology, land use patterns, and overall character and identity. The following details significant architectural elements distinct to traditional Jeddah residential structures using a gendered lens.

\subsection{Entrances}

Entrances were transitional spaces, and in Al-Balad houses, we find gender operating heavily. Jeddah's traditional houses had two entrances: one was semi-public, used for male guests, and the other one was a semi-private, used for family and female guests [9]. The main door was located in the front of the house, centrally placed with a decorated wooden doorway that was sometimes flanked by niches forming a tripartite composition common in Islamic architecture [10]. The other entrance door is located on a quieter street that had less traffic to insure the privacy of the women of the house and her guests. Both doors led to the corridor or entry vestibule (dihliz). The dihliz was flanked by one or two raised maqa'ad, a guest majlis salamlik, where male visitors were received or business was conducted. The other entrance led to the women majlis haramlik.

Because women occupied the house more constantly than men their comfort was a priority. The circulation of air in the house had to be optimal to keep them comfortable and healthy, while allowing them to feel the best of the weather outside and not its blistering heat. Furthermore, to protect the privacy of the women of the household, the staircase had no direct view into the rooms of any floor. An example, Bayt Nassief's main entrance was on the north side (Fig. 1), preceded by a flight of steps. From this side, the house looked out onto a small square with a tree, one of the few trees found in Jeddah at that time. The motifs carved in the wood of the main double doors to the house include a tree and sun motif. Another entrance to the house was found on the west side of the building. 


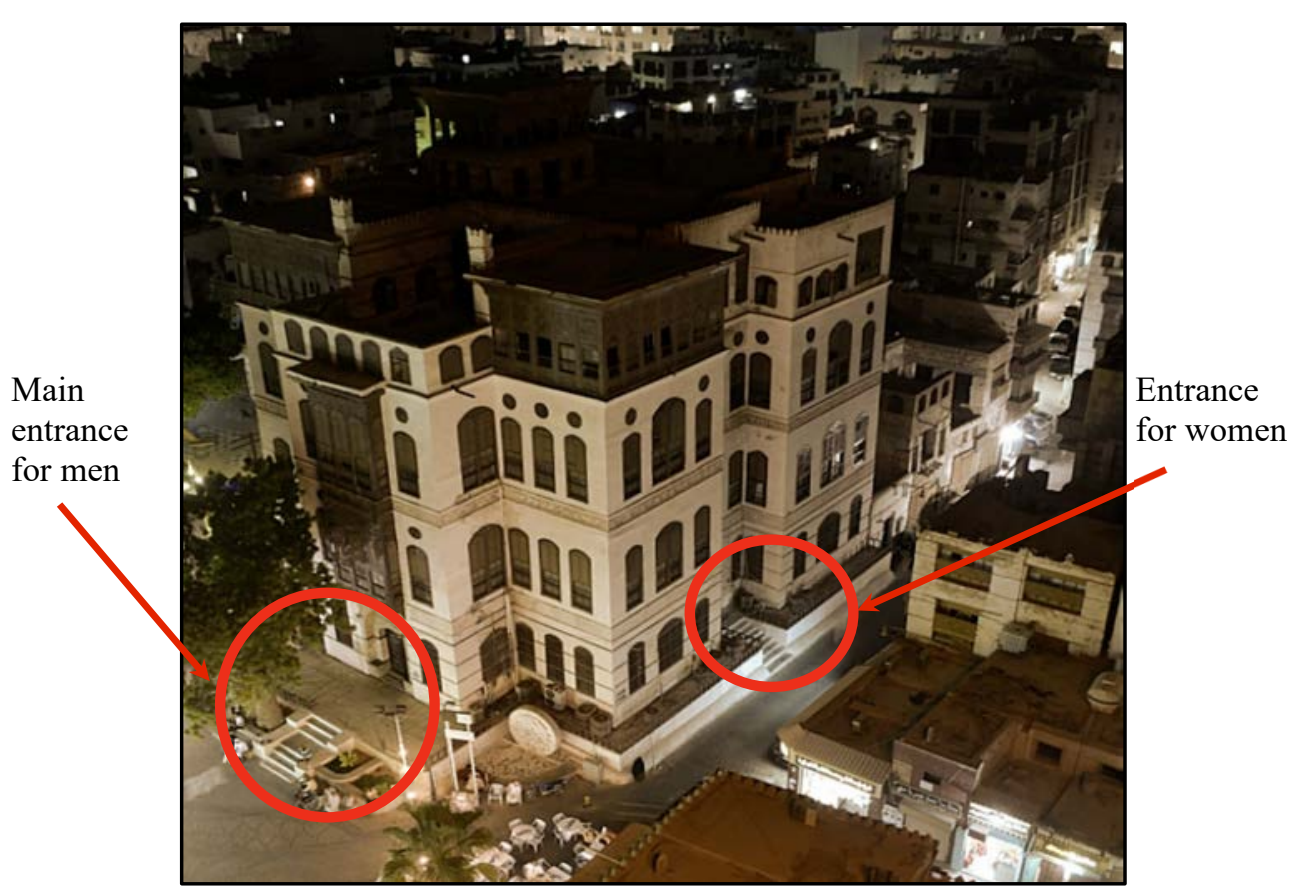

Figure 1: Bayt Nassif entrances. (Source: Najat Majed Photography, www.flickr.com/photos/najatmajed/7996972886/.)

\subsection{Doors}

Bab or door is a major use of wood in the houses of Jeddah was for doors. They were typically a double leaf design, decorated with carved panels showcasing the finest details of wood carving in the Arab world. The two entry doors to the house were the most decorative. They were usually taller than the other doors and featured some extra plaster decoration on the mantle.

\subsection{Majlis}

In Arabic, a salon, or parlor, is called majlis, but in Hijaz, the majlis can be further categorized by gender: haramlik for women's majlis and salamlik for men's majlis. These categories, much like the rooms themselves, differentiated the men from the women and emphasized the importance of women and how they too were considered individuals.

In the Nassief house, the finest decoration was found in the women's haramlik on the fourth-floor because this was the main majlis of the house. Access to this majlis was further dignified by round arches resting on columns with ornate floral capitals. The only glass in the house was used in lunettes over these doors, allowing the sunlight to appear as bright, primary colors. For Bayt Nassif, much like other traditional Islamic Arab houses, there is a clear separation of public and private spaces.

On the other hand, the majlis located on the first floor was much smaller than the haramlik because men usually met, prayed, and entertained outdoors. Both majlis, furthermore, were far away from each other to insure the privacy of the women and to maintain their freedom. 


\subsection{Terrace}

The terrace of the Al-Balad houses was a crowning architectural element that no elite home would lack. Set high on top of the tower house, the terrace functioned in the way a courtyard for a courtyard house would have. Because the houses do not have any other external, fenced gardens or protective enclosures outside the buildings due to the lack of land availability within the town of Jeddah, the terrace provided access to the outdoors. In some houses, the space was considered an outdoor majlis, and was occasionally used for family gatherings and celebrations. Wooden screens enclosed the terrace to offer privacy for family members. Placed in the center was a high kushk, such as was noted in Bayt Nassief (Fig. 2). The kushk functioned like an outdoor resting space. Often family could be found sleeping on the terrace during the hottest months, because it was cooled by the breezes found at this height. A parapet around the roof and the tops of the walls of the kushk was surmounted by crenellations, providing a site for more decoration both on the interior and exterior of the space.

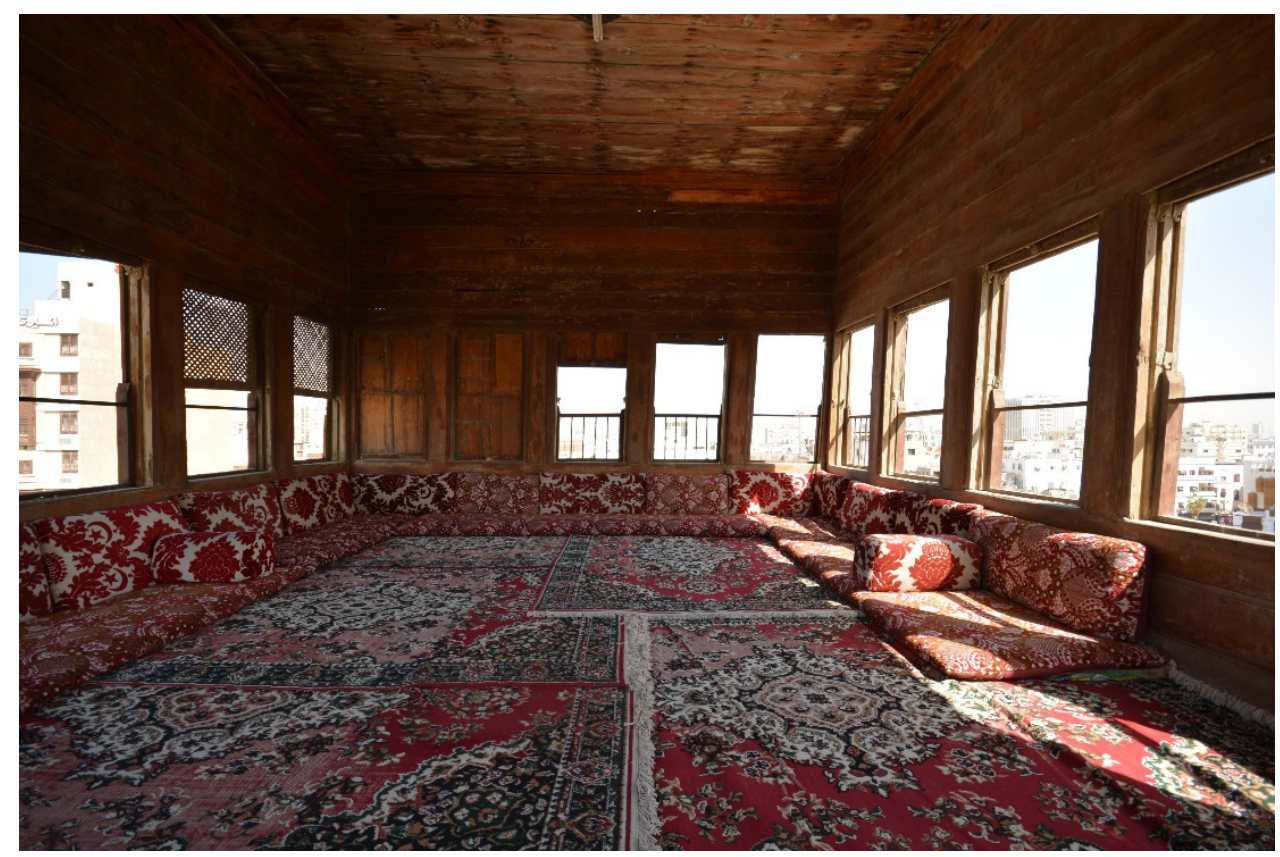

Figure 2: Kushk bayt Nassief, July, 2015. (Source: Author.)

Similar to the kushk was the Al-mabit, another significant architectural response to climate. This was a small structure, typically built of paneled wood with louvers and a light roof, used for sleeping in the summer. For women, the terraces enabled them to see outdoor, domestic activities such as drying clothes, having a meal with the family, playing with children, or taking tea in the afternoon, all while being protected from the rabble and noise of the street below and nearby neighbors.

The interior and the exterior of the terrace were made of wood that was decorated with the finest craftsmanship. The screens enclosed the haramlik on all four sides, allowing ventilation and sunlight to enter the space. While the wooden screens ensured the privacy 
and the freedom of the women, they also allowed for women of the home to gaze out from the height at the vibrant goings on about the city, such as weddings, Friday prayers at the Mosque, Jami and the talk of the Imam, football games and funerals.

When considering the terrace and its design as a space occupied and managed by the head woman of the house, its significant to consider how elevation and viewing functioned (Fig. 3). Typically the terrace was positioned above the main entrance of the home, on the corner of the busiest street. This location offered interesting opportunities for knowledge. From this height, women had the best view of other houses, particularly those at lower levels. This allowed women of higher terraces to see into others' homes while preserving their own privacy. This privilege gave these women information about their neighbors. Such knowledge empowered women by the mere fact of having knowledge lacking in their peers. Information about a family's interactions, quarrels, management of servants could be valuable information for a woman of the day, gaining her a certain authority - or lack of it - over her peers.

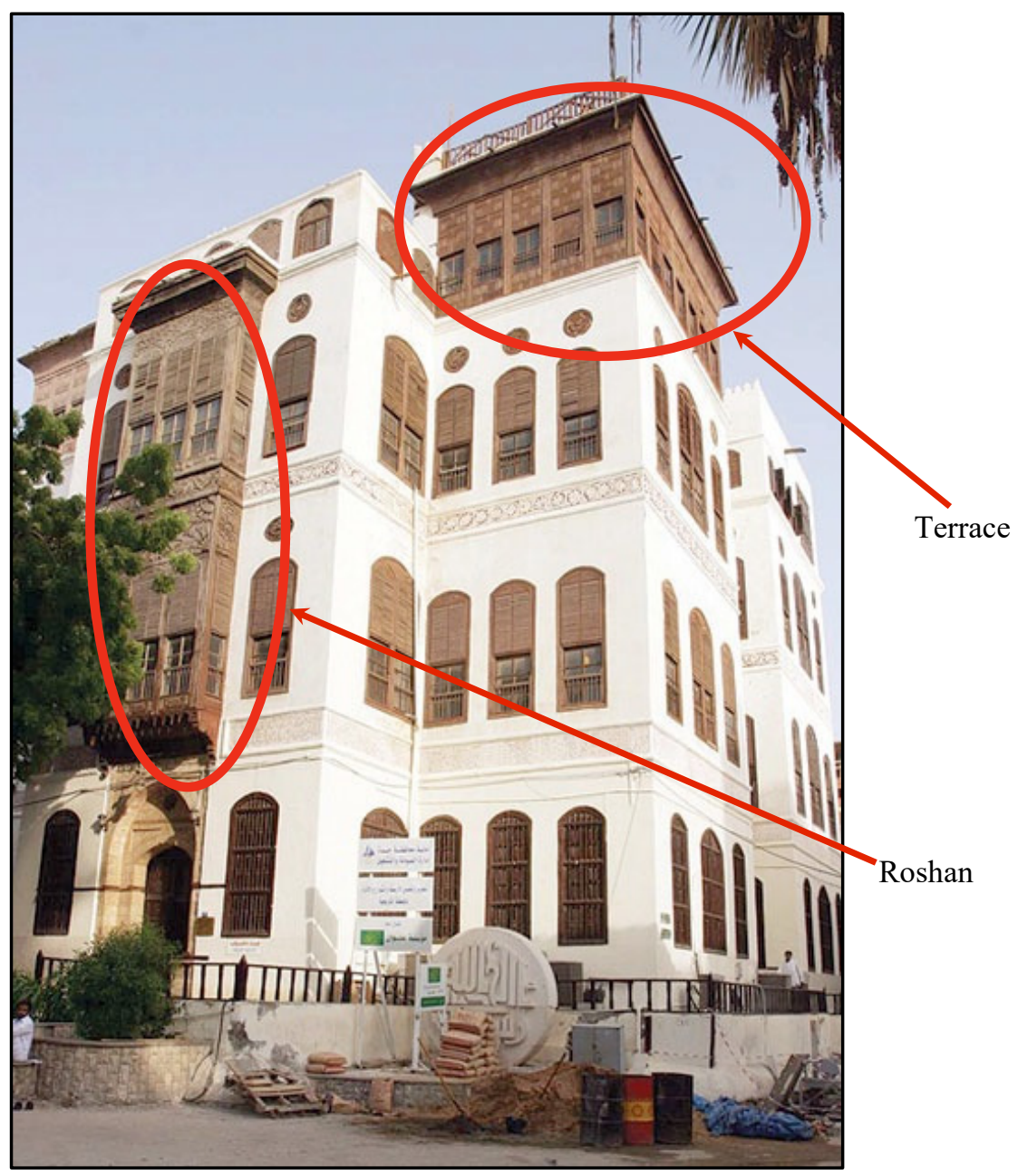

Figure 3: Terrace at Bayt Nassief, July, 2015. (Source: Author.) 


\subsection{Roshan}

The Roshan is one of the most characteristic elements of the Tower House's exterior. It is also one of the most sophisticated elements of the traditional architecture of the Hijazi house. It more than any other element speaks of the presence of a woman.

In terms of function, the roshan was part of the elaborate ventilation system that cooled the Hijazi house. Located on the upper floors, roshans covered openings in the exterior walls (Figs 4 and 5). As figure five reveals, the structure of the roshan was a three-sided wooden box that projected outwards or cantilevers from the exterior face. From the interior, the roshan was a seating area nearly the width of a full-sized bed (about 1.2 to $1.4 \mathrm{~m}$ ) and tall enough for an average person to stand $(2.4$ to $2.7 \mathrm{~m})$ [6]. The space within the roshan was mainly used to rest and to enjoy the sunlight and the cool breezes coming from three sides. Traditionally, the roshan and its windows did not contain glass panes, using instead a lattice of wooden slats or boards called shish that were built around the lower half to conceal the interior when the upper shutters were open. The shish (Fig. 6) functioned to increase the privacy of the interior, to prevent visual intrusion from the street, and to provide the women with visual access to the exterior.

Much in the culture of Islam has influenced the design of the traditional house. But it may surprise those with misconceptions of women's authority within Islam that the design of the house reveals her culture and social agency which carries over into respect for her in the public realm.

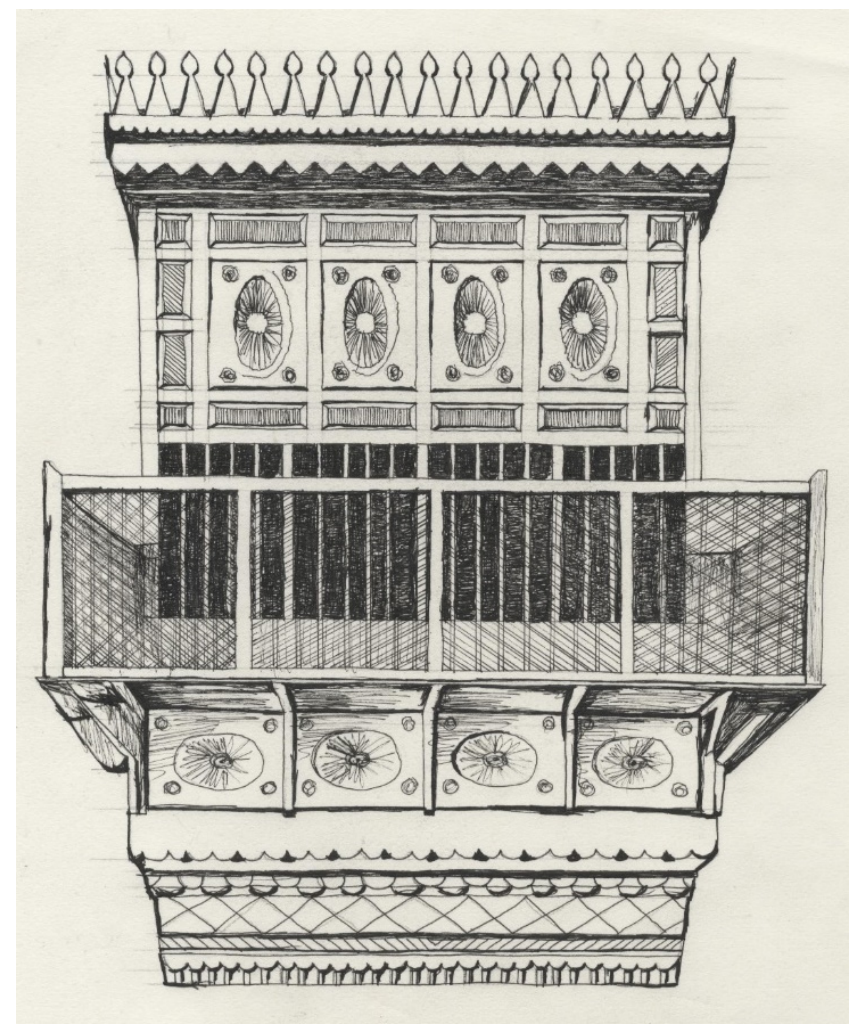

Figure 4: Roshan. (Source: Author.) 


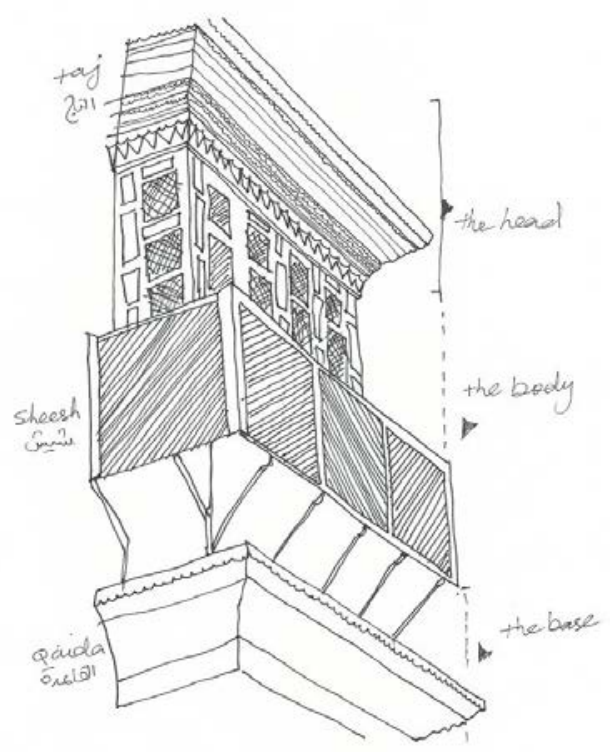

Figure 5: Sketch of roshan. (Source: Author.)

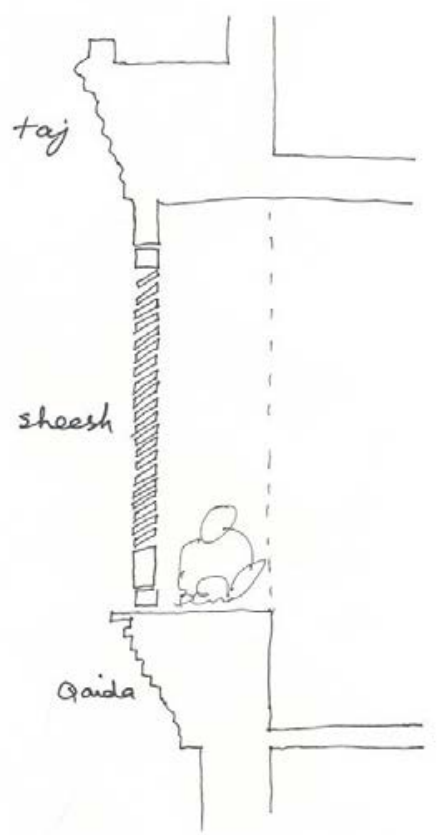

Figure 6: Roshan section sketch. (Source: Author.) 
Glossary of Arabic terms

\begin{tabular}{|c|c|c|}
\hline $\begin{array}{l}\text { Arabic word } \\
\text { pronunciation }\end{array}$ & Arabic text & English definition \\
\hline Al-Balad & البلد & $\begin{array}{l}\text { The village, the city. But in Jeddah slang it } \\
\text { means original area of downtown Jeddah }\end{array}$ \\
\hline $\mathrm{Bab}$ & باب & Door \\
\hline Bayt & بيت & House \\
\hline Dihliz & دهليز & Entry hall \\
\hline Hajj & حج & The Islamic pilgrimage \\
\hline Haramlik & الحرملك & Women's reception room \\
\hline Hijaz & الحجاز & West region of Saudi Arabia \\
\hline Imam & إمام & Prayer leader \\
\hline Jami & 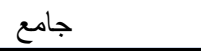 & Friday mosque \\
\hline Kabaa & كعبه & $\begin{array}{l}\text { A cubed building in Makkah where all Muslims } \\
\text { face when praying }\end{array}$ \\
\hline Kushk & كثلك & Private sitting room \\
\hline Majlis & مجلس & Reception room \\
\hline Mashrabiya & مشربيه & Screen of turned wood \\
\hline Muhasana & محصنه & Women to be guarded by her husband \\
\hline Qur'an & قر آن & The Holy book for Islamic faith \\
\hline $\begin{array}{l}\text { Roshan (s.) } \\
\text { Rawasheen (pl.) }\end{array}$ & روشان & Casement \\
\hline Salamlik & سلاملك & Male reception room \\
\hline Shish & شيش & Wooden lattice screens \\
\hline Sura & سوره & Chapters in the holy Qur'an \\
\hline
\end{tabular}

\section{REFERENCES}

[1] Sadalla, E.K., Vershure, B. \& Burroughs, J., Identity symbolism in housing. Environment and Behavior, 19(5), pp. 569-587, 1987.

[2] Ragette, F., Traditional Domestic Architecture of the Arab Region: Edition Axel Menges, pp. 27-41, 2003.

[3] King, G., The Traditional Architecture of Saudi Arabia, IB Tauris: London, p. 48, 1998.

[4] Qur'an, 24:27.

[5] Salem Sharif, M., Zain, M.F.M. \& Surat, M., Concurrence of thermal comfort of courtyard housing and privacy in the traditional Arab house in Middle East. Australian Journal of Basic and Applied Sciences, 4(8), pp. 4029-4037, 2010.

[6] Al-Lyaly \& Sameer Mahmoud, Z. The traditional house of Jeddah: A study of the interaction between climate, form and living patterns. $\mathrm{PhD}$ dissertation, University of Edinburgh, 1990.

[7] Bray, B. \& Darlow, M., Ibn Saud: The Desert Warrior who Created the Kingdom of Saudi Arabia, Skyhorse Publishing: New York, 2013. 
[8] Mahmood, S., Politics of Piety: The Islamic Revival and the Feminist Subject, Princeton University Press, pp. 2-14, 2011.

[9] El-Shorbagy, A.-M., Traditional Islamic-Arab house: Vocabulary and syntax. International Journal of Civil and Environmental Engineering IJCEE-IJENS, 10(4), pp. 15-20, 2010.

[10] AlHarbi, T.H., The development of housing in Jeddah: Changes in the built form from the traditional to the modern. PhD dissertation, University of Newcastle, 1989. 